\title{
The depreciation of the great jubilee: the celebrations of the 1150th anniversary of Russian statehood in Novgorod the Great (2012)*
}

Outline of content: The article is devoted to the subject of the 1150th anniversary of the Russian Statehood celebrated in September 2012. It was the liberal political commentary writings accompanying the original model of the jubilee celebrated in 1862 that was used as the point of reference of the rhetoric of the celebrations' initiator, the President of Russian Federation Dmitry Medvedev. This made the president of Russia refer very often to the "Era of the Great Reforms" (the 1860s, and 1870s). The article describes the course of the jubilee celebrations with the accompanying information campaign in the public mass media, as well as a failed legislative action to make the symbolic anniversary of the origins of the Russian Statehood a National Day.

Keywords: Russia, liberalism, commemoration, jubilee, collective memory, Alexander II, Dmitry Medvedev

It is one thousand years! How much do minutes [of the jubilee] matter?! Involuntarily, a chain of moving events sweeps through our imagination; succeeding one another, generations walk by in rows, martyrs of the world, martyrs of truth, militants of will, heroes of faith and thought, outstanding individuals - leaders of the masses, colourless masses unwittingly walking in the footsteps of the guiding thread, imprinted against their desire, rise from the ancient ashes of forgotten graves; the old life sheds its age-old mould; we hear the groans of early faded hopes, forces wasted in vain, laments of millions of sufferers, who died in periods of heavy misfortunes, without the participation of the contemporaries, not bewailed by their offspring and forgotten by history - animal debauchery of arbitrariness, quiet sadness of hopeless suffering. ${ }^{1}$

N. Kostomarov

* This article is part of the research project Histories and Memories of Empires in Eastern Europe: Interactive Studies, headed by prof. dr. hab. Andrzej Nowak. In the years 2012-2014, the author was a scholarship holder under the MASTER programme funded by the Foundation for Polish Science.

1 Н.И. Костомаров, “Тысячелетие”, Санкт-петербургские ведомости, 5 (09.01.1862), р. 24. 
In the 21st-century world, Russia should be a sovereign and influential state against the background of the new system of economic, civil, and military forces. Not only should we be developing confidently, but also preserving our national and spiritual identity, and not disappearing as a nation. To be and to remain Russia. [...] For the sake of revival of national consciousness, we must combine historical eras in one and return to the understanding of this simple truth that Russia began not in 1917, and not even in 1991, but that we have one, unbreakable one-thousand-year history. Based on it, we gain inner strength and a sense of national development. ${ }^{2}$

V. Putin

\section{Preliminary remarks}

The political history cultivated today may not disregard the achievements of related fields, particularly historical anthropology, which locates the epicentre of its interest in the sphere of culture, including socio-political and economic issues. The latest Russian historiography rightly lends much importance to projections of the mind and everything that is conducive to their creation in accordance with the wishes of power, supported not only (and not even especially) by coercion, but also by authority. ${ }^{3}$ Any serious attempt to describe the phenomenon of power must take into account the cultural mechanisms of its operation, and its representations. Strictly speaking, this issue is not new and already Max Weber made legitimacy the central problem of social sciences. This approach assumes that the symbolism used by those in power is to strengthen the faith of the governed in the officially declared values which support political order. ${ }^{4}$

This article aims to introduce the celebration of the $1150^{\text {th }}$ anniversary of Russian statehood - an anniversary which is seemingly fundamentally important for the historical consciousness of the Russians, and for the elites in power. Organizers of great jubilees did not attach particular importance to the corrections of historians sometimes questioning the accuracy of calculations of the author(s) of The Tale of Past Years (or The Primary Chronicle), who by their authority ordered to consider the year 862 as the moment of initiation. It is hard to be surprised by that offhandedness with regard to chronological precision: a definite decision on when the beginning took place might never be made, and is not of primary importance. After all, it is not about a point in time, but about what in the second millennium of Russia's existence results from such a long duration. An interesting

2 В.В. Путин, Послание Президента Федеральному Собранию, 12 декабря 2012 года, http://kremlin.ru/events/president/news/17118 (access: 03.09.2014).

3 J. Baszkiewicz, Władza, Wroclaw, 1999, esp. pp. 5-7.

${ }^{4}$ М.М. Кром, "Политическая антропология: новые подходы к изучению феномена власти в истории России”, Исторические записки, 122 (2001), no. 4, pp. 374-376; K. Pomian, "Historia - dziś", in: Historia - dziś. Teoretyczne problemy wiedzy o przeszłości, eds. E. Domańska, R. Stobiecki, T. Wiślicz, Krakow, 2014, pp. 21-22. 
thing: it had taken a thousand years before this question was asked in the context of the initial date. An even more interesting thing: it happened at a time when the Russian Empire was entering a new path, i.e. in "the era of great reforms". It will seem a paradox that "modernity is turning towards the past. If it rejects what is ancient, it is trying to shelter in history". ${ }^{5}$ The familiarization with the then Russian reception of the past in itself seems to be cognitively compelling. What purpose would it serve to include in the analysis the subsequent celebrations, organized in completely different historical circumstances? Let the rationale be a statement of the British anthropologist and sociologist Paul Connerton, who in the now classic work from a quarter century ago wrote that "the most powerful self-interpretations [of societies] are the images of themselves as continuously existing that societies create and preserve". ${ }^{6}$ The ceremonies organized in 2012 explicitly referred to the celebrations from a hundred and fifty years ago, thus embedding the current efforts in tradition and continuing (developing) the modernizing narrative of the days of Alexander II.

Moving within the circle of issues concerning the relationship between tradition and modernity, it is impossible to disregard the following question: what is the essence of the relationship between modernization tasks and historical policy? From the point of view of the authority reforming the state, the past is an invaluable resource serving social mobilization; for it is a known fact that without the participation of ordinary people transformations fail, since administrative methods are not enough. Attributing the Russian ruling elite "a sovereign monopoly on historical interpretation", Ilya Kalinin, a historian associated with Saint-Petersburg State University, describes the current policy of the Kremlin as "a conjunction of the nanotechnology of the future with the mnemotechnology of the past". In his opinion, the predominant mechanism for regulating symbolic space in Russia is the monopolization of cultural resources and counteracting any attempts to undermine this hegemonic position. Such treatment of the past causes that inexhaustible resources become limited and non-renewable goods, and the dispute about the past is transformed into a zero-sum game, in which the victory of one side must inevitably mean the defeat of the other. Under these conditions, historical policy becomes brutal and it happens so for the purposes of modernization. ${ }^{7}$ I do not intend to argue at this point with the essence of Kalinin's diagnosis, even though the material presented below seems to indicate that the ability to use all available historical instruments by the Russian authorities is fairly unlikely. ${ }^{8}$

${ }^{5}$ J. Le Goff, Historia i pamięć, transl. by A. Gronowska, J. Stryjczyk, Warszawa, 2007, p. 99.

${ }^{6}$ P. Connerton, How societies remember, Cambridge, 1989, p. 12.

7 I. Kalinin, "The Struggle for History: The Past as a Limited Resource", in: Memory and Theory in Eastern Europe, eds. U. Blacker, A. Etkind, J. Fedor, New York, 2013, pp. 256, 260-261.

8 The thesis of the St. Petersburg researcher seems worth considering in a wider context: "how do the changes of macro-institutional configurations and politically-legitimising discourses that occurred during the post-socialist democratization condition the creative and critical 
Although the article deals with the political dimension of the jubilees of Russian statehood, it is placed quite distantly from the research perspective reducing the studies of Russia to the realm of politics detached from culture. The excessive politicization of the look at Russia prevents the perception of the universal nature of the phenomena occurring there. Reflection on the difficult course of Russian history confirms the intuition of the Polish researcher in the field of cultural studies, who attributed the key role in the shaping of individual and collective identities to collective memory. Drawing on Pierre Nora's achievements of pioneering research on memory, the scholar sees in the growing interest in the past an attempt to compensate for the losses caused by the fragmentation of memory due to the dynamics of the change that accompanies modern and post-modern society. ${ }^{9}$ The cultural slant of the analysis allows to cool the excitement with the political side of the projects aimed at interfering with identity, since it makes one aware of the practical difficulties of effectively imposing anything on human memory. These difficulties are reflected in the lack of automatic translation of a newly emerged visual sign of some space into memory; the power of impact of symbolic space is limited. ${ }^{10}$

\section{The ideological setting of the jubilee of the $1000^{\text {th }}$ anniversary of Russian statehood - the liberal reflection}

In this article I do not set myself comparative tasks: it is not my intention to confront the motivations of organizers of the celebrations or to compare the course of their events. In the case of the nineteenth-century jubilee it would be futile, since it had been extensively described in the literature of the subject; next to the already classic study of the semiotics of power by Richard Wortman, who devoted to it one subchapter, ${ }^{11}$ we have at our disposal a masterly sketch of the Russian researcher - an in-depth and comprehensive analysis. ${ }^{12}$ The mentioned

commemorative reception of concepts of the nation and modernization?”; А. Лангеноль, “Общественная память после смены строя: сходства и различия между практиками памяти в посткоммунистических и постколониальных странах”, Ab Imperio, 1 (2004), p. 380.

9 B. Korzeniewski, "Wprowadzenie. Przemiany pamięci społecznej z perspektywy teorii kultury - polskie i niemieckie przestrzenie pamięci”, in: Przemiany pamięci społecznej a teoria kultury, ed. B. Korzeniewski, Poznań, 2007, p. 9.

10 С.А. Еремеева, "Монументальные практики коммеморации в России XIX и начала XX века", in: Образы времени и исторические представления: Россия - Восток - Запад, ed. Л.П. Репина, Москва, 2010, pp. 906, 910.

11 Р.С. Уортман, Сиенарии власти. Мифы и иеремонии русской монархии, vol. 2: От Александра II до отречения Николая II, Москва, 2004, рр. 117-131.

12 О. Майорова, “Бессмертный Рюрик: Празднование тысячелетия России в 1862 г., Новое литературное обозрение, 43 (2000), pp. 137-165, also online: http://magazines.russ.ru/ nlo/2000/43/s6.html (access: 03.09.2014). 
authors subject to vivisection the intentions of the ruling elite, by making them part of the legitimisational discourse. ${ }^{13}$ From my point of view, the value of the two studies lies in the fact that in no uncertain terms do they show the anchorage of the political dimension of the jubilee in the historical, and even cultural (self-)consciousness of the observers-participants of/in the holiday. The millennium jubilee, as unanimously proven by historians, was an authentic experience of the Russian subjects of the empire (to what extent of the subjects of the Russian Empire in general is another matter, requiring detailed studies). This statement entitles us to recognize the year 1862 as one of the important nodes of memory of the descendants of those events, living in the twenty first century, and claiming this heritage. ${ }^{14}$

If I give up discussing the ceremonial aspect of the millennium jubilee, I do so in the conviction that the re-exploration of the same sources will not bring anything new to the findings of the above mentioned scholars. Rather than duplicate the efforts of my predecessors, I decided to present only a selection of occasional journalism, printed on the pages of the most important liberal periodicals. This decision was dictated by a significant circumstance, i.e. President Dmitry Medvedev, the initiator of the jubilee of the $1150^{\text {th }}$ anniversary, often alluded to the liberal values of those days (which will still be discussed). So far, the press material used by me has not been examined with the aim to extract from it the main features of a liberal political agenda. ${ }^{15}$ I present three texts performing the functions of ideological manifestos, published in influential newspapers: the daily Sankt-Peterburgskye Vedomosti [Saint-Petersburg News] (Санкт-Петербургские ведомости), the weekly The Contemporary Chronicle (Современная тетопись), the monthly Otechestvennye Zapiski [Notes of the Fatherland] (Отечественные запискu). The Chronicle was the press organ of Mikhail Katkov (1818-1887), a liberal-westernizer, who after a few years would move to conservative positions, only

${ }^{13}$ The discussions presented in them seem convincing, although it should be borne in mind that not all participants in those events attributed so much significance to them, for example, as in the account of the then Minister of War, Dmitry Milutin, written many years later: Д.А. Милютин, Воспоминания. 1860-1862, еd. Л.Г. Захарова, Москва, 1999, pp. 386-391.

${ }^{14}$ I might add right away that a possible objection according to which the mythologisation of the past cast a shadow over the vision inspired by Alexander II and his entourage and presented 150 years ago, does not change anything here. Indeed, as noted by the Russian researcher, historical myths still remain an important form of social consciousness, because they are also an integral part of cultural traditions; С.В. Конорев, “Исторический миф в современном российском обществе: происхождение и социокультурная роль”, in: Кризисы переломных эпох в исторической памяти, еd. Л.П. Репина, Москва, 2012, pp. 332-333.

15 A global (should we believe the announcement of the self-report of the candidate paper) press panorama of the millennium jubilee of Russian statehood was presented by А.И. Буслаев, Имперские юбилеи - тысячелетие России (1862 год) и девятисотлетие крещения Руси (1888 год): организация, символика, восприятие обществом, a doctoral dissertation, Москва, 2010. Its author did not structure the analyzed texts for their ideological slant. The work contains the most extensive in the literature source bibliography on the topics of interest to me. 
to become in the 1880s, as an editor of Moscow News (Московские ведомости), the main ideologue of Alexander III's policy. In turn, consistently promoting liberal values, Andrzej Krajewski (1810-1889), one of the capital's most influential publishers and the future owner of the daily Voice (Голос), the most frequently daily newspaper read in the 1870s, was the editor of Notes and News, leased from the Imperial Academy of Sciences.

Attempts to give meaning to the 1000-year existence of the Russian state were clearly marked in the liberal journalism of those days. We will not find any selfaffirmation there; on the contrary, self-criticism is clearly visible. A columnist of Saint-Petersburg News observed that the unprecedented territorial expansion of the Russian Empire did not constitute an autotelic purpose. Indeed, the spectacular growth of the state, whose birthplace was a small area near Lake Ilmen, took place over ten centuries. Russia's control extends as far as the Carpathians in the west, the icy deserts of North America in the east, the polar pole in the north and the arid steppes of Central Asia in the south. The Russians "forced to respect their power" both the uncouth Americans and cultured Parisians, the author observed with satisfaction. Soon, however, he added that they had not guessed the real purpose of their aspirations, although they felt it instinctively. ${ }^{16}$

According to the journalist of the capital daily, the beginning of the second millennium of Russian history marks a new stage in the building of the statehood. However, each structure must rest on a solid foundation. Fortunately, a foundation for the challenges of the new era is already established: the Manifesto of February 19, 1861 leaves no doubt that all attention should be directed to the people, namely the peasantry. The author of the essay observed with clear satisfaction that, in the Russian Empire, the great change symbolized by the release of the peasants from serfdom, was made by the will of the rulers. It was different in the West, where it had been preceded by social upheavals, bloody class conflicts, revolutions. The liberal commentator did not content himself with this praise of the authorities, he did not hesitate to step on the slippery slope of political futurism. If Russia was to effect the world's coup, he mused, then it would not consist in taking control of further stretches of the planet, but in the practical dissemination of the utopias much dreamt about by Western philosophers, which become realized in the Russian people (nation). The faith in the mission of their homeland authorized the opinion that the past of the Russian Empire, marked with numerous conquests, was not at all sterile, but only prepared ground for its glorious future. ${ }^{17}$

The conviction that Russia was entering a new era, visible in the quoted reasoning, was not anything special. This point of view was most distinctly articulated in The Contemporary Chronicle. The following extract from the anniversary

\footnotetext{
16 Д., “862-1862”, Санкт-петербургские ведомости, 1 (03.01.1862), p. 1.

17 Ibid., pp. 1-2.
} 
articles provides a good example of the way of thinking of the liberals gathered in the editorial office of the magazine. A commentator of Katkov's magazine excluded the coincidence of the abolition of serfdom with the great jubilee. According to him, the simultaneity of the two events was an expression of the will of providence. The $19^{\text {th }}$ February Manifesto was the final act of the passing millennium, the building of the "All-Russian State", marked by enormous effort and shed blood. Historic fate had the decision made: making representatives of all estates free men ended the settlements of the past centuries, and closed the past. From that time on, a new life, as well as other hardships and challenges began. ${ }^{18}$

The essence of the liberal argument of The Contemporary Chronicle was in the successful combination of imperial and modernizing threads. According to the author of the text discussed, paradoxically, the power of Russia favoured the individual and social development of its subjects. The 1000-year effort meant that the Russian state was supported by solid foundations and in the new era it did not have to focus on survival: the immovability of these foundations allowed to focus on national life. At last, the state was able to fulfil its purpose: the removing of obstacles to the free development of the subjects is a compensation for the sacrifices made earlier. Moreover, the use of the initiative and energy of people is simply an objective necessity of historical development. In the opinion of the author, an attempt to evade this route would prevent Russia not only from moving forward, but even from maintaining a balance. Denying society the right to autonomy would harm the empire, it would undermine its unity and weaken its political significance. What occurs here, explained the journalist using another term, is feedback: the power of the state derives from national life and is directly proportional to the contribution to its development and the level of conditions of existence provided to it. In other words, at the foundations of imperial existence lies moral force, whose life depends on the extent of freedom of operation of its carriers. ${ }^{19}$

The relationship described by the associate of Katkov's editorial board was for the then Russian liberals of axiomatic nature. How they justified such a position using references to national history is worth determining. It is all the more important that it allows to figure out what the inheritance of non-autocratic Rus' meant for the generation of the era of great reforms. From among the texts on these issues, probably the most comprehensive study was published in the "Notes of the Fatherland". Its author was Nikolay Kostomarov (1817-1885), a humanist of different specialties, poet, social activist of Ukrainophile inclinations, the then full-time lecturer and professor of history at the University of St. Petersburg. At this point, Kostomarov's article interests me only as a reflection of the liberal

\footnotetext{
18 “Праздник тысячелетия России в Новгороде”, Современная летопись Русского вестника, 37 (September 1862), p. 12.

19 Ibid., p. 13.
} 
viewpoint on the history of Russia, so neither do I carry out a thorough analysis of the statements contained in it, nor do I confront them with other ideological currents of contemporary Russian historiography.

Kostomarov was interested in the antinomy of two political principles: monocracy and district principalities, with the assembly (вече) as the central authority. He believed that the struggle between these extremely different forms of political life was the axis of the history of the Russian state, and its result in favour of the former by no means diminished the value of the latter. It results from this fact that the Russian character shaped under the influence of both of them. According to the historian, Novgorod the Great was no exception compared to the other organisms of medieval Rus', and the institution of the assembly was an expression of autonomy of individual lands typical for those days. In the view of the Novgorodians, striving to maintain independence was not contradictory to the need for maintaining close links with the other political entities of the eastern Slavs, or the territorial integrity of Russian lands. The failure of the federal model was determined by the Tatar-Mongol domination. Although it did not affect Novgorod the Great directly, this centre become only a rump of a superpower. Meanwhile, democracy, combining the requirements of ancestral rights with respecting personal freedom, could only be adopted on the whole Russian territory, but never on its part. Moreover, the spreading and deepening of freedom depended on "the spirit, level of mental development, on ideas about moral and social duty", and conditions conducive to it were, due to objective circumstances, unfavourable. The optimistic tenor of Kostomarov's text was supported by the conviction that after hundreds of years of subordination of Novgorod the Great to the princes of Moscow (the times of Ivan III), statehood and nationality finally came to terms with each other. The centuries-old struggle of monocracy and sovereignty came to an end. Nothing could threaten the power of the state, the activity of its subjects would in no way hurt it any more. The history of Russia begins somehow anew - concluded the learned journalist. ${ }^{20}$

The three interpretations discussed above were not uttered in unison. Indeed, it is difficult to resist the impression that they share important common features, and it is them that authorize the treatment of the articles cited above as an authoritative source of knowledge about the mood of liberal circles at the dawn of the era of great reforms. The then Russian liberals saw the jubilee year 1862 as a "watershed" separating two eras: the era of hypertrophy of the state in social life, and the era of equal coexistence of power and its subjects. The end of the first millennium was marked by the release of peasants from serfdom, placing freedom on a pedestal both actually and symbolically. In the opinion of the cited authors (and the circles behind them), broadening the scope of individual freedom was

${ }^{20}$ Н.И. Костомаров, “О значении Великого Новгорода в русской истории”, Отечественные записки, 140 (January 1862), pp. 84, 88, 92-93, 95-96, 99, 102, 104. 
a necessary condition for the growth of the imperial power of Russia. Still more, further sequestration of freedom would do harm to the Russian Empire. This optimistic vision of the coming times derived from the recognition that the objective development of socio-political relations allowed two equivalent values, i.e. statehood and nationality, to develop peacefully. Since then, the prosperity of one of them was not implemented at the expense of the other, because their goal was also common - the enhancement of the status of classes not yet enjoying full civil rights. In such a distribution of journalistic focuses, there was certainly much noble naivety, which found its fullest expression in the Virgilian phrase "iam nova progenies caelo demittitur alto", quoted by one of the authors. ${ }^{21}$ It is impossible, however, to question the authenticity and sincerity of liberal commentators when they claimed that an entirely new order was being developed. Similar opinions demonstrate the sincerity of efforts to change the status quo.

Reminding in this article of the journalistic voices from half a century ago is not a matter of chance: liberal periodicals endorsed the reform projects initiated by Alexander II and the so-called liberal bureaucrats. Knowing what interested the then authorities and public, as well as how arguments for change were constructed, is a natural point of reference for the discourse of modernization presented by Medvedev, holding the highest office in Russia in the years 2008-2012. The conviction of the President of the Russian Federation of the affinity of "the era of great reforms" and his rule too clearly resounded in the keynote speech of 3 March 2011, delivered at the conference "The great reforms and modernization of Russia". ${ }^{22}$ Given this circumstance, the forgotten 1862 jubilee journalism ceases to be only an antiquarian monument. Its reading (as well as the knowledge of the journalism of the 1860s and 1870s) provides grounds to challenge the widespread and simplistic judgements about the Russian modernization as a project initiated solely in order to strengthen the position of the ruling. ${ }^{23}$ More importantly, it undermines the straightforward juxtaposition of the imperial and liberal model

${ }^{21}$ This is the eighth verse of Virgil's mysterious Eclogue IV. Citing a few verses preceding it will help to capture its meaning: "Ultima Cumaei venit iam carminis aetas; / Magnus ab integro saeclorum nascitur ordo. / iam redit et Virgo, redeunt Saturnia regna / iam nova progenies caelo demittitur alto". Or, as one English translation has it: "Now is come the last age of the Cumaean prophecy: / the great cycle of periods is born anew. / Now returns the Maid, returns the reign of Saturn: / now from high heaven a new generation comes down"; transl. by J.W. Mackail, Virgil's Works: The Aeneid, Eclogues and Georgics; Whitefish, 2003, pp. 275-276.

22 Cf. an analysis of this speech in the subchapter "Contemporary interpretations and contexts of the tsar-liberator era" in my unpublished doctoral dissertation Reformy a zmiana społeczna $w$ Rosji Aleksandra II. Dymitr Milutin i gazeta "Gołos" w sporach o kształt oświaty i armii, Jagiellonian University, Krakow, 2015.

23 Among others, J. Potulski, "Współczesny rosyjski dyskurs modernizacyjny", in: Fenomen Rosji. Pamięć przeszłości i perspektywy rozwoju, part 2: Kontekst polityczny i gospodarczy, eds. J. Diec, A. Jach, Krakow, 2014, p. 127; M. Broda, “Rosyjska idea' i problemy modernizacyjne Rosji”, in: Bariery modernizacji Rosji, eds. S. Bieleń, A. Skrzypek, Warsaw, 2014, p. 71. 
of Russian modernization. ${ }^{24}$ In fact, some trends of pre-revolutionary liberalism supported imperial projects, and even more: imperial Russia seemed to them an effective promoter of liberal ideals.

\section{The celebration of the $1150^{\text {th }}$ anniversary of Russian statehood in Novgorod the Great (2012)}

\section{The intentions of the originators - the vision of President Dmitry Medvedev}

The "jubilee" intentions of President Dmitry Medvedev may be inferred from the materials made available to the public, primarily from the video recordings of meetings of the head of state with the representatives of state bodies responsible (in terms of content and logistics) for the preparation of the celebrations. The leader of Russia first heard the opinion of several invited historians representing various academic centres and the Russian Academy of Sciences, then held a conference with members of the executive committees of the two presidential councils: the Council for Culture and the Arts and the Council for Science, Technology and Education (currently: of Science and Education). Both meetings were held in Vladimir on the Klyazma on 22 July $2011 .^{25}$ The choice of the location was not accidental: the rulers of the Suzdalia-Vladimiria, including the north-eastern part of Rus', which were Russia's rump territories, successfully fought for political primacy in Ruthenian lands, which found its expression not only in their use of the Grand Duke title, but also in moving the seat of the Metropolitan of Kiev to the capital of their state. Although it was the dukes of Moscow that brought about the unification of Ruthenian lands, however, in the universal consciousness, belonging to the so-called Golden Ring, Vladimir remains Moscow's ancestor, perhaps due to the action of Andrey Bogolyubsky (the second half of the $12^{\text {th }}$ century), who took the title of Grand Duke, and it was there that he moved the capital from Kiev. Regardless of the source of such associations, the choice of the museum complex in Vladimir as the site of presidential consultations added importance to the working meetings and distinguished them from other routine meetings filling the calendar of Russia's leader.

Participants in both meetings spoke on various issues, and conceptual and organizational matters of the planned celebrations of the $1150^{\text {th }}$ anniversary,

${ }^{24}$ S. Bieleń, "Szanse modernizacji na tle osobliwości rosyjskiej polityki”, in: Barriers, pp. 217-218.

25 The video recordings along with the stenographic records were made available by the press service of the Kremlin. Since the President's opinions were complementary to each other (they largely overlapped), I discuss them collectively. Cf. Встреча с учёньми-историками, http:// www.kremlin.ru/news/12073 (access: 03.09.2014); Заседание по вопросу подготовки к разднованию 1150-летия зарождения российской государственности, http://www.kremlin. ru/transcripts/12075 (access: 03.09.2014). 
although the formally leading ones gave way to an exchange of views on issues of general nature, concerning the prospects for improving the condition of historical sciences, the historical consciousness of the Russians and the ways of shaping it, and finally the relationship between history and politics. Providing an account of all of these opinions would go beyond the scope of this article, whereas the views of the host of the meeting seem to be incomparably more important for the issues raised here. It seems right to begin with the presidential motivation in referring to the symbolic birth of Russia. Medvedev shared with the assembled his doubts accompanying the signing of the decree on the celebrating in 2012 of the origins of Russian statehood; reportedly, he hesitated for a few months whether to do so. He was afraid of setting a precedent (?!) of determining by the state the rightness of one scientific theory, still contested by some researchers. Indeed, announcing a decree is equivalent to raising the Normanist theory to the rank of a normative act, with all the legal consequences of this fact. Ultimately, however, he decided to take this step, considering that its positive aspects outweigh the negative ones, and the risk of error is reduced by the consensus of most scholars as to the veracity of the historical interpretation of the surviving sources of material and spiritual culture.

What did the Russian president have in mind when speaking about the positive aspects of the official celebration of the jubilee of the establishment of Rus'? The answer to this question can be found in the laconic text of the Decree of 3 March 2011 proclaiming that the purpose of the planned celebrations is the "further consolidation of Russian society". ${ }^{26}$ In the light of this statement, the practical dimension of the planned celebration becomes the primary objective and induces to perform an analysis of the rest of Medvedev's speech, which deals with the foundations of statehood, which is crucial for the understanding of the way of thinking not so much about the past centuries of Russian history, but above all about the present time. Beforehand, however, the source of inspiration from which the leader of the Russian Federation drew needs to be identified. Wishing to celebrate the very beginnings of the country governed by him, he alluded directly to Alexander II and stressed that over the hundred and fifty years following the tsar-liberator no one decided to revive this initiative. Medvedev, who holds the era of great reforms in high esteem, drew a parallel between that era and contemporary reality, attributing the intention to bring closer the power and the nation to the promoter of the nineteenth-century transformations. Usurping the ambitions to modernize the state, the Russian president compared the complexity of the then and today's situation, thus finding in the native history an argument for the necessity of consolidation, especially a national consolidation.

26 Указ Президента РФ “О праздновании 1150-летия зарождения российской государственности” 3 марта 2011 года N 267, http://old.rs.gov.ru/sites/rs.gov.ru/files/1_-_Ukaz_Prezidenta_ RF_03_03_2011.pdf (access: 03.09.2014). 
It may be assumed that Medvedev's opinions which resounded on 22 July 2011 announced the theses of the future jubilee speech. Two strands of thought are particularly worth mentioning. Firstly, the president was highly critical of the presentation of national history in a spirit of self-humiliation, so common in journalism. He was referring to the inadmissibility of interpretation of Russian history in terms of a state which owes both its establishment and further development only to contacts with Western European culture, since it could not create or achieve anything on its own. Medvedev's argument is interesting because it does not appeal to national pride or anti-Western resentment, but it emphasizes the high level of the legal culture of Rus'. From the very beginning, he claimed, Rus' developed as a state under the rule of law: well-established principles of conduct governed interpersonal relationships and supported the social order; they influenced not only how people lived, but also what kind of values they professed. Law was closely linked with justice, which allowed to settle conflicts in accordance with the truth. An important role in the enforcement of justice was performed by the authority, which took care of the development of the state, guarded the interests of subjects, tended the diverse traditions of the people of the vast territory. According to the President of the Russian Federation, wrong and harmful are the negativistic concepts manifested in challenging the thesis on the law being an important factor holding together the Ruthenian state. Endorsing them would in fact deprive today's ambitions to follow a democratic path of legitimacy, and would move Russia back by a whole century.

Secondly, Medvedev pointed to polyethnicity as a constant for the development of Russia from the first moments of its existence. In his opinion, the history of Ruthenian statehood was subordinated to the logic of unification, because fragmentation was treated as an indicator of weakness. It was different with cultural and religious diversity, which were not perceived as a potential threat. For more than eleven centuries, Russia was a separate "multinational civilization, possessing a unique ethnic and cultural potential", so every effort should be made to ensure that tolerance and mutual respect, typical of the Russians, invariably remain a norm for society. The President maintained that the strongest proof of the universality of such an attitude is the longevity of the state itself. Had it been otherwise, had there been no "force unifying different people", such an enormous community would not have survived, sharing the fate of many creations that vanished forever. Although Medvedev's projection idealized the relations prevailing in the Russian state, passing over the chauvinist tendencies of the Russian element, after all, he acknowledged that polyethnicity constituted and would constitute in the future one of the sources of problems faced by the ruling elites in Russia. However, if the country is to survive, they must, on the one hand, maintain this diversity, on the other hand, they must find a solution to the contradictions that are inherent in complex organisms.

One other moment in Medvedev's speeches is worth noting. The President explicitly stated that the development of the state is impossible without "points 
of consensus". A consistent position on the major events of the past is, according to him, the "main route" followed by the nation, the state, and even humanity. Abandoning occupied positions may be fateful, thus, with regard to key issues (e.g. the Great Patriotic War), a consensus among society and the establishment allows to avoid moving in an undesirable direction. The speaker explained that he meant only the sphere of education: young Russians should gain in school the knowledge of how their country had developed, while in science various interpretations of the same events are permissible. Formulated in the technocratic language, the speech emphasises the importance of historical policy, announcing a more consistent than ever use of tools for its conduct. This was not just an empty declaration of intent since the Russian authorities had made every effort to implement the postulate of the single direction in the school curriculum. ${ }^{27}$ Medvedev's assurances, that the content of all-national consensus does not necessarily have to be imposed by administrative bodies, did not sound convincing in this context. Discussing semi-formal speeches of the President of Russia, it is difficult to pass over the typical tendency for the mindset of the Russian political elites to describe phenomena in universalistic terms. Hints about general human population, suggesting that the consensus serving the cohesion of the Russian community is, in fact, what we all need, should perhaps be interpreted in this way.

\section{The plan and course of the ceremonies}

The idea that the celebrations of the $1150^{\text {th }}$ anniversary of the beginnings of Russian statehood would become a nationwide holiday, was dispelled by the Government Regulation of 6 February 2012 approving 63 planned undertakings. ${ }^{28}$ It was conclusive on their basis that the authorities did not anticipate any central celebrations. The funds in the amount of 450 million roubles $(80 \%$ of which came from the central budget, $10 \%$ - from the budget of the various administrative entities, the rest from other sources, including sponsors) were divided into several categories of expenditures. The lion's share of the funds (380 million roubles) was spent on the "memorialisation of sites of memory", i.e. the restoration of neglected buildings of historic importance, especially kremlins and religious buildings. The supervision of the work carried out in Old Ladoga, Novgorod the Great, Vologda, Bielozyersk, Rostov the Great, Pskov, Kostroma, Staraya Russa was exercised by the Ministry of Culture. Relatively small amounts were allocated for the organization of five scientific conferences, preparation of three museum exhibitions, issuing seven scientific and popular publications, and finally the creation of an internet

27 Cf. А. Каспшыцка, "Реформа системы образования в России и формирование исторической памяти граждан”, in: The phenomenon of Russia, pp. 109-116.

28 Распоряжение Правительства РФ от 06.02.2012 N 153-р “О плане основных мероприятий по подготовке и проведению празднования 1150-летия зарождения российской государственности", www.consultant.ru/document/cons_doc_EXP_524549 (access: 03.09.2014). 
project-exhibition. Quite small sums would be spent on the organization of festivals, competitions, rallies, parades and historical reconstructions, the subject of which was sometimes very loosely connected with the main celebrations. It seems characteristic that the shooting of a non-feature film dedicated to the $1150^{\text {th }}$ anniversary of statehood (barely 2.6 million roubles), organization of the conference "North-West - the cradle of the Russian statehood", holding another linguistic congress in Yalta (Ukraine), and shooting a documentary series devoted to the role that individual nations played in the establishment of the state, were found as the most important projects. Apparently, the authorities decided to develop in parallel a number of projects targeted at different environments, while none of these events was to become a point of reference for the others.

In this situation, the burden of setting up a program of the jubilee celebrations planned in Novgorod the Great rested on local authorities. The three-day celebrations began on September 21, the day of the $150^{\text {th }}$ anniversary of the unveiling of the monument of The Millennium of Rus' by Alexander II (21 September today is the equivalent of 8 September 1862, since the difference between the Julian calendar used in pre-revolutionary Russia and the Gregorian calendar used today is 13 days). The theme of the first day was the religious face of the city, depicted as an ancient centre of Orthodox culture, while the symbol of that heritage was a bell. At 9 a.m. in the Museum of Fine Arts (the erstwhile building of the assembly of nobility), a bust of Alexander II was unveiled. The sculpture carved by Albert Tcharkin is a smaller copy of the statue of Tsar-Liberator (by the well-known sculptor, Alexander Opiekushin), which was erected in Rybinsk (Yaroslavsky District) in 1914, and lasted only four years. At about 10 o'clock, a two-hour liturgy, which was attended only by previously invited people, began in St. Sophia's cathedral. From there, at noon, a procession set off heading for the statue erected on the occasion of the $1000^{\text {th }}$ anniversary of Russian statehood, where a service with a sermon was held. At 1.00 p.m., a half-hour performance presenting the History of the Russian state was shown in a square located nearby. Then, the ruler's hall (грановитая палата) restored in the kremlin was presented. At this point, the programme was split. At 5.00 p.m., on the square at the Manezh sports complex, a monument in honour of the Novgorod militia in the Patriotic War of 1812 was unveiled. An hour later, the first sounds of the two-hour concert of the Academic Symphony Orchestra of St. Petersburg Philharmonic, conducted by Alexander Dymitriev, with soloists of the Mariinsky Theatre, and closed to the wider public, resounded in the philharmonic hall. At 9.30 p.m., on the river Volkhov, a half-hour fireworks show, closing the first day of the celebrations, was held. The afternoon and evening program was varied and participants could choose between the cultural and entertainment offers. Concerts were held in various parts of the city and the best bell-ringers presented their skills, brass bands trod in parades, choirs sang, and local artists played folk instruments; there were also local bands playing lighter music. Those willing to could spend their money 
at fairs, where agricultural and handicraft products were being sold. Still others had an opportunity to attend the opening of the festival of historical reconstructions, or to see, in the open air, a film about the history and culture of Novgorod the Great. ${ }^{29}$

In the organizers' intention, the second day of the celebrations was to show Novgorod land as the homeland of the great country. At 9.00 a.m., the exhibition "Rurik's fortified settlement - the oldest princely residence" was opened in the kremlin, Two hours later, the official ceremony of the unveiling of the 2.6-metrehigh and 40-tonne "Duke's Stone", on which a fragment of the chronicle telling about the calling of Rurik had been engraved beforehand, was held. ${ }^{30}$ Closed to the general public, the ceremony almost literally moved invited participants in time, which was taken care of by the reconstruction performers (on the agenda was the $4^{\text {th }}$ Festival of Historical Reconstruction): guests arrived at the place in boats, and on the hill above the Volkhov warriors from the $9^{\text {th }}$ century were "stationed". At 3.00 p.m., in the main square of the city, the official opening ceremony of the jubilee celebrations was held, which was first graced by the briefing of the cavalry escort of honour of the Russian president, which was then followed by the parade of individual regions of Novgorod district and Novgorod organizations. Another important point on the agenda was the reception of the guests by the acting district governor combined with the awarding of state decorations. The evening, on the other hand, was pure entertainment; it was filled with an outdoor concert given by the stars of the Russian show business. Just like on the first day of the anniversary, also this time those willing to could pick from the cultural program, choosing according to their preference more ambitious or typically entertaining events, a common feature of all of them being obviously folklore. The same spirit permeated the third day of the celebrations, highlighting the moments of glory of the Russian army in Novgorod lands. Narrowing down to important things, only the forenoon unveiling of the panneau, made in the relief technique, on the stelas of the place of memory "The city of the glory of war" in Voskresenskiy boulevard, seems worth mentioning. Each of the four stelas is devoted to a different period of the history of Novgorod land: the $10^{\text {th }}$ century 1478 (Rus' until the incorporation of the Novgorod Republic into the Grand Duchy of Moscow), 1492-1721 (Moscow Rus', or Muscovy), 1721-1917 (the Russian Empire), 1917 to the present day. ${ }^{31}$ Other points of the programme were either very loosely linked to the ideological message of the jubilee, or, just like the afternoon

${ }^{29}$ http://www.1150russia.ru/programma-yubileya.html (access: 26.03.2015).

30 “И прия Рюрикъ власть всю одинъ, и пришед къ Ильмерю, и сруби городок надъ Волховом, ипрозваша и 'Новъгород, и седе ту, княжа, и раздая мужемъ своимъ волости и городы рубити". Cf. the Polish translation of the passage from the chronicle treating of the year 862 - The Primary Chronicle, transl. and ed. by F. Sielicki, Wroclaw, 1999, pp. 15-16.

31 В Великом Новгороде открыли рельеф-панно на мини-стелах мемориала "Город воинской славы", http://news.novgorod.ru/news/101350/ (access: 03.06.2015). 
demonstration flights over the Volkhov, were orientated towards the ludic nature of the anniversary days.

\section{The media message - accounts on the nationwide TV channels}

In the era of information hegemony of electronic media, the most reliable indicator of the significance that the Russian authorities attach to some events, is the accounts on national television channels. The Internet exerts its influence here to a much lesser extent, probably due to the low availability which is limited to major urban centres. We should then look closer at the reflection of the official celebrations of the $1150^{\text {th }}$ anniversary in news programs.

The first channel of Russian TV devoted to them barely 44 seconds in the evening news edition of 22 September 2012 (this topic did not appear in any other broadcast), marking the seventh position in the order; more time was spent on telling the story of a kleptomaniac cat which robs residents of one of British cities under the cover of night. The material highlighted the entertaining nature of the event. The viewers could find out that next to Rurik's fortified settlement a parade of historic ships from various historical periods was held, which was entitled From the Varangians to the Greeks, crowned with cannon salutes. Next, the scene of calling Rurik to Novgorod Great and images from the early days of the city's history were acted out. Then, a "commemorative sign", i.e. the 40-tonne "Duke's Stone", was placed inside the fortified settlement. The last point of the program was a fireworks show on the Volkhov. ${ }^{32}$

Even more brief account (38 seconds) of the Novgorod celebrations on 21 September 2012 was given by the news channel Russia 24. Indeed, in the four sentences devoted to the celebrations they managed to fit not only the information on the events accompanying the celebrations - the bell art festival, concerts of brass bands, the fair and exhibitions of folk art - but also that the ceremonies began with the liturgy in the cathedral of Novgorod kremlin, following which the participants went to the monument of The Millennium of Rus'. ${ }^{33}$ The jubilee of the beginnings of Ruthenian statehood was completely passed over by the channel Russia Today, directing their messages to the non-Russian audience looking for an alternative to American $\mathrm{CNN}$ or European EuroNews.

The most extensive coverage of the celebrations of the $1150^{\text {th }}$ anniversary of the Russian statehood was provided by NTV channel. The chronologically first material from 21 September 2012 (shot by the St. Petersburg branch of NTV, within the focus of which is entire north-western Russia) was limited to general

32 В Великом Новгороде отмечают памятную дату: 1150 лет зарождения российской государственности, http://www.1tv.ru/news/social/216055 (access: 03.06.2015).

33 Великий Новгород отмечает 1150-летие государственности Руси, http://rutv.ru/brand/show/ episode/159912 (access: 03.06.2015). 
information, richer than in the aforementioned ones by the announcement of the unveiling of Alexander II's bust, and the presence of governor of Leningrad Oblast. ${ }^{34}$ On the next day, i.e. 22 September 2012, a 2-minute and 36-second report from Novgorod the Great was presented to the audience. The correspondent began it with a remark that the idea to celebrate the anniversary of statehood in a city that for centuries refused to join in any country, demonstrates a sense of humour which, actually, from the very beginning accompanied the Novgorodians. He subsequently added that the location of legendary Rurik's residence on the Volkhov is not exactly known. According to the reporter, the place where Russian statehood originated would not impress anyone today. Only the erratic boulder, remembering ancient times, with an engraved quotation from the Chronicle makes us realize what past is hidden on the hill with the ruins of buildings. Unlike in the above-discussed examples of TV coverage, the bell was mentioned in the context of the assembly, or the tradition of parliamentarism. In the further part of the coverage, the reporter talked about the commercial traditions of Novgorod, at the time on a par with the most powerful centres of Europe, and about the fact that it deserved to be called a "window to Europe", which it had remained long before the foundation of St. Petersburg. In short, the city made a significant contribution to the development of Russian statehood and has more than one reason to be proud (it can be concluded from the tone of the statements that it is not only about being a precursor in making shoes separately for the right and left leg, although putting in similar remarks says a lot about the actual attitude to the jubilee)..$^{35}$

The conducted review makes it easier to discern the common feature of the accounts provided by the most influential electronic media, i.e. the recognition of the local rather than all-state nature of the Novgorod celebrations. In this way, they were degraded to the status of a festival. No account of the ceremonies was enriched with a reflection on the sense of honouring the symbolic date of the birth of Rus', no-one wondered what were the sources of the stability of Ruthenan (Russian) statehood, no attempts were made to inquire what all this meant for the next generations. The very fact of celebrating the jubilee the $1150^{\text {th }}$ anniversary of the East Slavic community in Novgorod the Great was not passed over, but it was deprived of any political significance. Certainly, the dim presence of this event on television was not a matter of chance. On the contrary, it reflected the level of involvement of the highest authorities and of the Orthodox Church hierarchy.

34 В честь 1150-летия в древнем русском городе начались массовые гуляния, http://www.ntv. $\mathrm{ru} /$ novosti/338097 (access: 03.06.2015).

35 В Великом Новгороде заложили камень в основание российской государственности в честь ее 1150-летнего юбилея, http://www.ntv.ru/novosti/338421 (access: 03.06.2015). 


\section{The aftermath: the virtual exhibition of the $1150^{\text {th }}$ anniversary of Russian statehood}

A material trace of the jubilee of the $1150^{\text {th }}$ anniversary of Russian statehood is a virtual exhibition organized at the initiative of the Federal Archives Agency (Федеральное архивное агентство) and the State Archive of the Russian Federation (Государственный архив Российской Федерации - GARF), with the active participation of seven other archives. As we already know from the preceding discussion, the Internet exhibition was a flagship project planned by the originators of the celebrations. This circumstance prompts one to have a careful look at its contents. The exhibition consists of eleven display cabinets, and each of them presents a different period of history of the state. And here they are: the Old Ruthenian state (древнерусское государство); the disintegration of the Old Ruthenian state into separate principalities; the Grand Duchy of Moscow and the principalities of north-eastern Rus'; the establishment and development of the unified (единое) Ruthenian state; the Time of Troubles; the Tsardom of Muscovy; the Russian Empire; the February Revolution and the fall of autocracy, the Provisional Government; the October Revolution, the Soviet state; the Soviet Union; the disintegration of the Soviet Union, the rise of the Russian Federation. What attracts attention is the extremely varied time span of the various periods: particularly conspicuous is the dismemberment of pre-Peter Russia and the treatment, juxtaposed with it, of two centuries (the eighteenth and the nineteenth) as an organic whole. Such a layout could confuse viewers accustomed to other divisions, such as the era of the reign of the Rurikids dynasty and the Romanovs. The authors of the exhibition chose the criterion of changing the formula of the state-political system, even if it did not have a radical character, i.e. it did not break down the framework of the legal system. The director of GARF explained in his foreword that the focus of the authors of the project was on the "very history of the Russian state", reportedly identified with the "history of Russian state institutions since their inception to the present day". Thus, the core of the exhibition is formed by the sets of laws "defining the nature of the Russian state", from Russkaya Pravda to the constitution of $1993 .{ }^{36}$ This declaration is a mirror image of the previously reported D. Medvedev's position, which is not surprising since the director of the state archives actually does clerical service and implements the directives of his superiors. However, the point is in something else: the defence of the presented point of view encounters practical difficulties because it requires proving that legal acts faithfully reflected the spirit of the Russian (and previously Ruthenian) political system; this, in turn, interferes with the awareness of the painstaking turns of building the rule of law in Russia, both at the end of the Tsarist era and at present. In other words, the message of

36 С.[В.] Мироненко, 2012 год объявлен годом российской истории, http://www.rusarchives.ru/ statehood/mironenko.shtml (access: 03.06.2015). 
this Internet project seems too optimistic, it is more like a declaration of intent than an assertion.

The relevance of the concept of the exhibition is a moot point, but it would be difficult to defend the implementation of the intention, because clearly no attention was demonstrated in this regard. Comments obviously lack a guiding thread, they were probably written by different people, without first consulting a coherent message. As a result, the viewer receives a portion of poorly composed information, in part from a history of events, and partly from a problem-oriented history. No care was taken of the continuity of the narrative (e.g. the discussion of the Russian Empire closes with the reign of Catherine the Great) or of its arrangement either. The selection of documents also gives the impression of randomness, even though the resources of the archives-participants in the project contain all the necessary materials. Becoming familiar with the virtual exhibition requires determination, because soon one comes to the conclusion that it does not fulfil its task, nor does it provide a sufficient overview of the history of Russia. Although photocopies of important legal acts (or rather their fragments) were made available, but there were no explanations that would make the reader aware of the importance of the given regulations. In the selection of the presented documents and in their descriptions it is difficult to discern a specific political thesis, yielding to outdated interpretive schemes, let alone the ill will of the authors of the exhibition. A good opportunity to present the achievements of Russian legal culture was certainly wasted, as evidenced by the lack of even a mention of Mikhail Speransky. In conclusion: the internet exhibition does not have a properly thought out structure, gives the impression of a chaotic collection of materials, and failing to provide visitors with a proper idea about the announced issues, it does not fulfil its task. Perhaps its blurred nature corresponds to the vague ideas of today's elites concerning the 1150-year-old heritage of Russia.

\section{Postscript: the project of establishing a new national holiday}

A meaningful postscript to the celebrating of the jubilee of the $1150^{\text {th }}$ anniversary of the beginnings of Russian statehood without excessive enthusiasm is the fate of the recent initiative aimed, in its intention, to establish (or rather, instil) the longue durée of the East Slavic political entity in social consciousness. Two deputies of the State Duma on behalf of the Liberal-Democratic Party of Russia, Mikhail Degtyarev (b. 1981) and Alexei Didenko (b. 1983), brought forward a proposal to change the federal law On the days of military glory and memorable dates of Russia $^{37}$ in such a way so as to include the symbolic date of Russia's birth. This

37 Discussion of the bill, cf. M. Banaszkiewicz, "O symbolach, uroczystościach i wychowaniu patriotycznym w Rosji”, in: Rozpad ZSRR i jego konsekwencje dla Europy i świata, part 4: Reinterpretacja po dwudziestu latach, eds. A. Jach, M. Kuryłowicz, Krakow, 2012, pp. 31-33. 
is not the first attempt to modify the calendar of state anniversaries made by the party of Vladimir Zhirinovsky; during the present, sixth term of the parliament, representatives of that environment have put forward similar ideas several times, but each time without success. If the latest proposal, dated 15 January 2014, did not remain unnoticed, it happened so because the authors of the draft amendment did not limit themselves in it to the supplementing of the list of events worth honouring, but also wished to remove one of the dates, additionally, one having the status of a state holiday. The gravity of the proposal calls for examining the motivations of the authors of the draft: an attempt of such radical interference in the system of symbols which organizes the memory of Russian society should not be underestimated, because it says a lot about both the moods among part of the political elites, and about the preferences of their voters.

In their justification of the bill, the deputies of the LDPR declared their will to raise the status of Russia Day. In their view, the memorable date (June $12^{\text {th }}$ ) celebrated under this name, reminiscent of the announcement by the Russian Federation of the declaration of state sovereignty, has not taken root in the social consciousness, as evidenced by opinion polls. Such a state of things, the authors say, is not a matter of chance: "The vast majority of the country's inhabitants do not want to combine the great word "Russia" with a political act which was a "harbinger of the tragic collapse of the USSR", and yet it is impossible to forget that this "was the deputies of the Russian Soviet Federative Socialist Republic who as one of the first announced the sovereignty of their Soviet republic". In the opinion of both members of the lower house of parliament, this fact negates the chance to make the annual June celebrations a public holiday consolidating the Russians. ${ }^{38}$ The clearly negative evaluation, from the point of view of the Russian Federation, of the collapse of the Soviet Union may not be surprising of the representatives of a political party openly proclaiming their devotion to the world power status, all the more so since for at least a decade, i.e. from the famous message of President Putin, delivered to the Federal Assembly in 2005, this view has gained the rank of little short of an axiom, even among politicians distancing themselves from the radical nationalist forces. At this point, however, another observation seems important: the symbol of the new, as intended, liberal-democratic opening in the history of the Russian state has not become the foundation myth of post-Soviet Russia.

The initiators of proclaiming the traditional date of the beginnings of Russia a national holiday chose the anniversary of the unveiling by Alexander II of the monument commemorating the Millennium of Rus' (September 20 of the new style). They claim that the preserved historical sources support the recognition

38 Пояснительная записка к проекту федерального закона "О внесении изменений в статью 1 Федерального закона" О днях воинской славы и памятных датах России "и в статью 112 Трудового кодекса Российской Федерации”, http://asozd2.duma.gov.ru/main.nsf/(ViewDoc)? OpenAgent\&work/dz.nsf/ByID\& EB21378905DBD8FC43257CCA0028524E, pp. 1-2 (access: 05.07.2015). 
of the year 862 as the beginning of the process of unification of tribes inhabiting the Eastern European plain under the auspices of the rulers of the Rurik dynasty. The distribution of accents in the justification of the project is quite typical: the authors consider to be crucial not the real relations of power in those territories, but the first recorded effort aimed at the "centralization of Ruthenian lands thanks to the active foreign policy of the Rurik dynasty", supported by the local population. According to the assumptions of the drafters, a new day in the calendar of anniversaries would be reminiscent of the "agreement between old Ruthenian tribes and Varangian leaders about the form of government in the territory of North-Western Rus". Writing about the "classical chronology of the history of Russia", which begins in 862, the LDPR deputies emphasized the uninterrupted continuity of the political community, despite the repeated shifting of borders, relocating the capital, and a number of systemic changes. This moment of argumentation reveals the sense of referring to the monument standing in Novgorod the Great since the days of the tsar-liberator: apart from the starting point in the $9^{\text {th }}$ century, there is no such date which would symbolize more than 1000-year-old Russian statehood. Apparently, the same conclusion was reached by the authors of the monument of the Millennium of Rus', since they also could not render the history of Russia by using a metaphor which would captivate one's imagination, but would remain readable. ${ }^{39}$

The amendment bill was not accepted for voting until 30 June 2015, which in itself says a lot about the "deference" with which it was treated, because according to the original agenda it was to be considered during the session of the State Duma already in October 2014. As expected, it was rejected at the June session due to the lack of quorum: the vote was attended by barely 66 deputies, including 56 from Zhirinovsky's party. The lacking in colour, twenty-minute discussion at the plenary session did not attest well to the intellectual abilities of the speakers, exposing their moderately high level of historical culture; however, it is worth a closer look in order to reaffirm that the drafters' motivations were exclusively negative (the desire to deprecate Russia Day), and the centuries-old perspective far exceeds the mental horizon of members of all parliamentary factions. ${ }^{40}$

It would be hard to obtain a more eloquent expression of the attitude of the ruling to the LDPR's proposal than the perfunctory reasons for the government's negative position on this issue. In a letter of 28 March 2014, Sergei Prikhodko, one of the deputy prime ministers, said that the event referred to by the drafters (the unveiling of the monument of the Millennium of Rus') indeed 'had a big social resonance", but today it is not seen as something significant. ${ }^{41}$ It is hard to argue

39 Ibid., pp. 2-3.

$40 \mathrm{http}: / /$ www.video-duma.ru/watch/?id=303230 (access: 5.07.2015).

41 Заключение на проект федерального закона «О внесении изменений в статью 1 Федерального закона "О днях воинской славы и памятных датах России" и в статью 112 Трудового кодекса Российской Федерации», вносимый в Государственную Думу депутатами Государственной 
with this statement. Contesting it would mean renouncing reality. Still, the official observation of the high representative of the executive makes everyone aware of the failure of the Russian political elites to make the jubilee of the $1150^{\text {th }}$ anniversary of statehood something more than just a series of more or less spectacular celebrations. In my opinion, it does not make credible the sometimes encountered view that Russia (and the CIS countries) represents a distinct type of the culture of memory, and its distinctive feature would be the attitude to the communist past. ${ }^{42}$ However, it attests perhaps the accuracy of an interesting, and deserving close reading political-scientific study by Nina Shcherbinina, according to which, in the symbolic sphere, Russia's political system rests on the archetype of the heroic ruler $^{43}$ ? A historian of the political history of Eastern Europe, who in exploring the well of memory and collective consciousness of the largest Slavic community strives to dig down to the underground spring feeding it, may find yet another hypothesis interesting. Being unable to worthily celebrate its birth, official modern Russia exposes the failure (perhaps inability?) to find a formula linking the various forms of government (not just mono- and autocracy, but also republicanism), and thus the different values that make up the political culture of Rus'. ${ }^{44}$

\section{Concluding remarks - an attempt at interpretation}

In search of a plausible scientific explanation of the essence of the jubilee celebrations of the Russian monarchy in 1862, a hint provided by an eminent researcher into the history of the French Revolution appears to be extremely helpful. Analysing the world of concepts of eighteenth-century revolutionaries and the symbolic policy implemented by them, she wrote: "Through the festival the new social bond was to be made manifest, eternal, and untouchable" ${ }^{45}$ At first glance, the recalling

Думы М.В.Дегтяревым и А.Н.Диденко, http://asozd2.duma.gov.ru/main.nsf/(ViewDoc)?Open Agent\&work/dz.nsf/ByID\&BBDEB49CE5B38F1743257CCA0036DF8B, p. 1 (access: 5.07.2015).

${ }^{42}$ For example, Ш. Требст, “ККакой такой ковёр?' Культура памяти в посткоммунистических обществах Восточной Европы: попытка общего описания и категоризации”, Ab Imperio, 4 (2004), pp. 55-56.

43 Н.Г. Щербинина, Мифо-герочческое конструирование политической реальности России, Москва, 2011.

${ }^{44}$ Incidentally, the above observation confirms the accuracy of the distinction made by the contemporary German researcher between a site of memory and a political myth. Lieux de mémoire are not the exclusive property of carriers of specific memory, whereas a political myth does not tolerate ambiguity and reflects a clear vision of those in power, which is to dominate the public space; H. Hein-Kircher, "Mythical reading of reality'. Constructions of reality, functions and influence of political myths on the culture of memory", in: Polish-German sites of memory, vol. 4: Methodological reflections, eds. R. Traba, H.H. Hahn, in co-operation with M. Górny, K. Kończal, Warszawa, 2013, esp. pp. 126-129.

${ }^{45}$ M. Ozouf, Festivals and the French Revolution, transl. A. Sheridan, Cambridge (MA)-London, 1988, p. 9. 
of this conclusion gives the impression of absurdity, since the celebrations of the millennium of existence of Russian statehood emphasized historical continuity. However, from the point of view of the proponents of reforms promoting changes on the pages of the liberal press, the second millennium of Russian history was to realize the ideals of freedom and equality of subjects-citizens. In this sense, the Novgorod celebrations gave a higher sanction to the values sanctifying the transformed social order (not political), thus challenging the rigid hierarchies based on the birth certificate. This assertion does not mean that Alexander II and his immediate circle were guided by egalitarian motivations. However, a holiday emphasizing the commonality of fate somehow unconsciously reduces inequalities: ${ }^{46}$ in the face of many centuries of history, which is, after all, impossible to be divided into the history of individual classes, the social distinctions of the community members no longer matter. In this, and only in this part (and not in being effusive with regard to the supposedly most important political context of the issue) the classic interpretation of the already referenced Richard Wortman appears to be legitimate: the "scenario of power" implemented by the tsar-liberator, assuming the gratitude to the lower classes for improving their lot, actually catalysed the cleavage of the traditional legitimacy of the monarchy, in spite of the executor of this scenario.

Strong is the temptation to charge Putin with responsibility for the overall shape of the jubilee of the $1150^{\text {th }}$ anniversary, who in the middle of 2012 again took office as the President of the Russian Federation and did not live up to the ex post declarations contained in his own speech at the joint session of parliament on 12 December of that year. The quotation from that speech opening this article must be all the more striking to the observers of Russian politics. It is highly probable that this action was not accidental: in this way, taking over the helm, Putin slighted Medvedev's concept, which refers - at least in its rhetoric sphere - to the liberal heritage of the era of great reforms. A series of public program speeches flirting with conservative circles (not only in Russia) ${ }^{47}$ becomes part of this strategy. However, at the beginning of this text, I signalled my intention of an interpretative turn in another direction, so I am not going to develop this thread, which is certainly worth a detailed analysis.

Perhaps the straightforward explanations attributing the failure of the celebrations of the $1150^{\text {th }}$ anniversary of Russian statehood to the light-heartedness of the current political elite should be rejected, and a deeper reflection should be encouraged. Despite the glaring differences between the two discussed jubilees, the same (albeit of varying intensity) dissonance can be felt in them. Conscious

46 This explains why so much importance was attached to the solemn celebration by the architects of the post-revolutionary order in France. Cf. J. Baszkiewicz, Nowy człowiek, nowy naród, nowy świat. Mitologia i rzeczywistość rewolucji francuskiej, Warszawa, 1993, p. 148.

${ }^{47}$ Cf. a block of texts published in Przeglad Polityczny, 130 (2015), pp. 20-57, devoted to this issue. 
participants in the holiday emphasizing the continuity of the largest Slavic state organization had to ponder over the axiological legitimacy of subsequent hypostases of Russia. Paradoxically, the "misguided" anniversary of 2012 only highlighted the inherent inconsistency of the message ${ }^{48}$ from before a century and a half ago. A statesman, an eyewitness of the then fête noted with satisfaction that "the past came alive before the present. Old Novgorod the Great united with that of today". All of this happened as if in defiance of the rulers who, "gathering Ruthenian lands", brutally broke the resistance of the Novgorodians: Ivan III and Ivan IV. Thus, the author of the memoirs seemed to claim that the libertarian tradition ultimately triumphed. ${ }^{49}$ On the one hand, the account quoted here proves how strong was in the early 1860s the belief in the possibility of reconciling autocracy with liberalism. On the other hand, however, it shows all too clearly that even then people realized that the Russian political tradition was by no means monolithic. Now, after 150 years, the above observation has only gained momentum. Pluralistic society cannot be led to believe in its homogeneity, because its members identify themselves with different traditions. ${ }^{50}$ This fact makes it very difficult to harmonize the meaning of the celebration of statehood, while this remark does not apply to Russia alone.

The course of the celebrations of 2012 induces reflection on the durability of commemoration efforts or rather the longevity of symbols strengthening the bonds of community. The elites are trying to propagate a certain message (and a system of values inseparable from it) in order for the community to become an authentic one, bound by a strong thread of agreement. The limit of effectiveness of these efforts and their mobilization abilities is determined by the existence of an emotional attitude of people to the object of commemoration, be it a date or a monument. ${ }^{51}$ This regularity is perfectly illustrated by the reception, changing in time, of the monument of the Millennium of Rus', evolving from fascination to indifference, as well as the fate of the initiative to make 20 September a national holiday. It is difficult to discern anything unusual here, the phenomenon being described by Jay Winter,

48 That inconsistency is functionally justified and should not be condemned. As noted by a Polish historian of ideas, "for any system of legitimization to work, it must be inconsistent. Different things are said to different recipients and different social groups, seeking to realize their aspirations, also use a different language of loyalty", M. Janowski [a voice in the discussion on the issues of humanist reflection], in: Historia - dziś, p. 334.

49 [П.А. Валуев], “8-е сентября 1862 года. Из воспоминаний современника”, Русская старина, 57 (January 1888), pp. 6-7.

50 The author of the text synthesizing the historical policy of Russia in recent years fails to notice the diversity of Russian political traditions (like the fact that the anniversary described here fell on the year 2012) and the difficulties in constructing a coherent patriotic pattern: W. Materski, "Polityka historyczna Federacji Rosyjskiej po 2000 r.", Dzieje Najnowsze, 4 (2014), no. 46, pp. 93-115, esp. p. 104.

51 Cf. R. Traba, "Dwa wymiary historii. Szkic na otwarcie”, in: id., Przeszłość w teraźniejszości. Polskie spory o historię na początku XXI wieku, Poznan, 2009, pp. 28-29. 
the Yale University professor who studies the relationships between history and memory. The American historian noted that sites of memory last as long as people are willing to attribute importance to them, not only (and not even especially) as a symbol of something important in the process of history, but above all as a moral directive. Since in the intention of their constructors lieux de mémoire are to be points of reference for future generations of recipients, the active participation of the latter is necessary: the absorption of erstwhile meanings alone is not enough, new ones have to be provided constantly. Sites of memory (the word "memory" here plays the role of a metaphor for the narrative of the past in accordance with the intellectual baggage of those who have been long since dead) are not eternal, but the initiators of public celebrations are doing their best to extend their expiration date infinitely. In reality, the process of disintegration is natural and what makes it inevitable is the gradually disappearing need to link the here and now to specific events in the distant past. By all means, this does not mean a decline in the interest in history. Old needs simply give way to new ones, but these can be satisfied only by other histories and sites of memory reminding of them. ${ }^{52}$ "The cohesiveness of commemoration" 53 of the beginnings of Russian statehood in 2012 against the background of the celebrations of 1862 came out disturbingly. Nothing strange indeed: the Russians did not undertake the "memory work" and they do not connect the "duty to remember" with the foundation act of their political community. ${ }^{54}$ Summarizing the research on the historical memory of the generation of reformed Russia, a modern Russian researcher pointed to the overwhelming social desire to perform historical self-identification, coupled with the desire to create collective identity. ${ }^{55}$ It is hard to resist the impression that today's Russian society does not show similar inclinations. ${ }^{56}$ This, however,

52 J. Winter, "Sites of Memory", in: Memory. Histories, Theories, Debates, eds. S. Radstone, B. Schwarz, New York, 2010, pp. 312-313, 324.

53 I took the term from: Я. Зарубавель, “Динамика коллективной памяти”, in: Империя и нащия в зеркале исторической памяти. Сборник статей, eds. И. Герасимов, М. Могильнер, А. Семенов, Москва, 2011, p. 19.

${ }^{54}$ Both terms (of which only the first one is valued positively, while the second one is seen merely as an empty imperative) are used by P. Ricoeur, "Pisanie historii a przedstawienie przeszłości", Przegląd Filozoficzny, 3 (2001), pp. 263-264.

55 О.Б. Леонтьева, “Историческая память и образы прошлого в культуре пореформенной России", in: Диалоги со временем: память о прошлом в контексте истории, ed. Л.П. Репина, Москва, 2008, p. 681.

56 This was also concluded by A.В. Святославский, История России в зеркале памяти. Механизм формирования исторических образов, Москва, 2013, pp. 447-448. Extremely meaningful in this regard is the fact that the two most important public opinion poll centres, i.e. the Russian Public Opinion Research Center (ВЦиОМ) and the Levada Centre (Левада Центр), did not carry out a single survey on the $1150^{\text {th }}$ anniversary of the Russian statehood. The contribution of the humanities and social sciences is also embarrassingly small: the jubilee did not find a scientific reflection on the pages of the majority of leading historical, political and sociological magazines. 
does not attest to the expiration of the liberal ideals of the era of great reforms. On the contrary: a reverberation of those aspirations and desires carries on like an echo of reproach that the tasks of the new millennium faced by Russia are far from being realized, despite the lapse of another 150 years.

\section{The depreciation of the great jubilee: the celebrations of the 1150th anniversary of Russian statehood in Novgorod the Great (2012)}

\section{Abstract}

The article is devoted to the subject of the 1150th anniversary of the Russian Statehood celebrated in September 2012. It was the liberal political commentary writings accompanying the original model of the jubilee celebrated in 1862 that was used as the point of reference of the rhetoric of the celebrations' initiator, the President of Russian Federation Dmitry Medvedev. This made the president of Russia refer very often to the "Epoch of the Great Reforms" (the 1860s, and 1870s). The article describes the course of the jubilee celebrations with accompanying information campaign in the public mass media, as well as a failed legislative action to make the symbolic anniversary of the origins of the Russian Statehood a National Day. In the conclusions, the author distances himself from the absolutisation of political causes (customary in the Polish writing blaming of the low political culture of the power elite) of the jubilee's failure. In the author's opinion, the main reason for the fiasco of the analysed enterprise lies in the difficulties to create a coherent historical narration which would combine various political traditions and their fundamental values.

The research, making the fundamentals of the text, subscribes to the interdisciplinary studies - flourishing in Poland these days - of collective memory and identity. The research perspective chosen by the author makes it possible to enrich the traditionally understood political history and history of ideas with the most recent achievements of historical anthropology. The purpose of this is to present not only a cultural context of the symbolic dimension of ars regendi (with the problem of legitimization of power at the lead), but also to discover the sources for the durability of symbols as invisible bonds tying the political community.

\section{Bibliography}

Banaszkiewicz M., “O symbolach, uroczystościach i wychowaniu patriotycznym w Rosji”, in: Rozpad ZSRR i jego konsekwencje dla Europy i świata, part 4: Reinterpretacja po dwudziestu latach, eds. A. Jach, M. Kuryłowicz, Kraków, 2012, pp. 23-37.

Banaszkiewicz M., "Reformy a zmiana społeczna w Rosji Aleksandra II. Dymitr Milutin i gazeta Gołos w sporach o kształt oświaty i armii", doctoral dissertation, Kraków, 2015.

Baszkiewicz J., Nowy człowiek, nowy naród, nowy świat. Mitologia i rzeczywistość rewolucji francuskiej, Warszawa, 1993.

Baszkiewicz J., Władza, Wrocław 1999.

Bieleń S., "Szanse modernizacji na tle osobliwości rosyjskiej polityki”, in: Bariery modernizacji Rosji, eds. S. Bieleń, A. Skrzypek, Warszawa, 2014, pp. 209-232.

Broda M., "'Rosyjska idea' i problemy modernizacyjne Rosji”, in: Bariery modernizacji Rosji, eds. S. Bieleń, A. Skrzypek, Warszawa, 2014, pp. 55-72.

Connerton P., Jak społeczeństwa pamiętają, Warszawa, 2012.

Goff J. le, Historia i pamięć, Warszawa, 2007. 
Hein-Kircher H., “Mityczne odczytanie rzeczywistości. Konstrukcje rzeczywistości, funkcje i wpływ mitów politycznych na kulturę pamięci”, in: Polsko-niemieckie miejsca pamięci, vol. 4: Refleksje metodologiczne, eds. R. Traba, H.H. Hahn, współpr. M. Górny, K. Kończal, Warszawa, 2013, pp. 123-132.

http://www.1150russia.ru/programma-yubileya.html (access: 26.03.2015).

http://www.video-duma.ru/watch/?id=303230 (access: 5.07.2015).

Kalinin I., "The Struggle for History: The Past as a Limited Resource", in: Memory and Theory in Eastern Europe, eds. U. Blacker, A. Etkind, J. Fedor, New York, 2013, pp. 255-265.

Korzeniewski B., "Wprowadzenie. Przemiany pamięci społecznej z perspektywy teorii kultury - polskie i niemieckie przestrzenie pamięci", in: Przemiany pamięci społecznej a teoria kultury, ed. B. Korzeniewski, Poznań, 2007, pp. 7-22.

Materski W., "Polityka historyczna Federacji Rosyjskiej po 2000 r., Dzieje Najnowsze, 4 (2014), no. 46 , pp. 93-115.

Ozouf M., Święto rewolucyjne 1789-1799, Warszawa, 2008.

Pomian K., "Historia - dziś", in: Historia - dziś. Teoretyczne problemy wiedzy o przeszłości, eds. E. Domańska, R. Stobiecki, T. Wiślicz, Kraków, 2014, pp. 19-36.

Potulski J., "Współczesny rosyjski dyskurs modernizacyjny", in: Fenomen Rosji. Pamięć przeszłości i perspektywy rozwoju, part 2: Kontekst polityczny i gospodarczy, eds. J. Diec, A. Jach, Kraków, 2014, pp. 119-139.

"Problemy refleksji humanistycznej" [discussion], in: Historia - dziś. Teoretyczne problemy wiedzy o przeszłości, eds. E. Domańska, R. Stobiecki, T. Wiślicz, Kraków, 2014, pp. 322-338.

Przeglad Polityczny, 130 (2015), pp. 20-57.

Ricoeur P., "Pisanie historii a przedstawienie przeszłości”, transl. J. Górnicka, Przegląd Filozoficzny, 3 (2001), pp. 261-274.

Traba R., "Dwa wymiary historii. Szkic na otwarcie", in: id., Przeszłość w teraźniejszości. Polskie spory o historię na początku XXI wieku, Poznań, 2009, pp. 11-64.

Winter J., "Sites of Memory", in: Memory. Histories, Theories, Debates, eds. S. Radstone, B. Schwarz, New York, 2010, pp. 312-324.

Буслаев А.И., “Имперские юбилеи - тысячелетие России (1862 год) и девятисотлетие крещения Руси (1888 год): организация, символика, восприятие обществом”, doctoral dissertation, Москва, 2010.

В Великом Новгороде заложили камень в основание российской государственности в честь ее 1150-летнего юбилея, http://www.ntv.ru/novosti/338421 (access: 3.06.2015).

В Великом Новгороде открыли рельеф-панно на мини-стелах мемориала «Город воинской славы», http://news.novgorod.ru/news/101350/ (access: 3.06.2015).

В Великом Новгороде отмечают памятную дату: 1150 лет зарождения российской государственности, http://www.1tv.ru/news/social/216055 (access: 3.06.2015).

В честь 1150-летия в древнем русском городе начались массовые гуляния, http://www.ntv. $\mathrm{ru} /$ novosti/338097 (access: 3.06.2015).

Великий Новгород отмечает 1150-летие государственности Руси, http://rutv.ru/brand/ show/episode/159912 (access: 3.06.2015).

Встреча с учёными-историками, http://www.kremlin.ru/news/12073 (access: 3.09.2014)

Еремеева С.А., “Монументальные практики коммеморации в России XIX и начала XX века", in: Образы времени и исторические представления: Россия - Восток 3апад, еd. Л.П. Репина, Москва, 2010, pp. 885-927.

Заключение на проект федерального закона "О внесении изменений в статью 1 Федерального закона «О днях воинской славы и памятных датах России» и в статью 112 Трудового кодекса Российской Федерации», вносимьй в Государственную Думу депутатами Государственной Думы М.В.Дегтяревым и А.Н. Диденко, http://asozd2. duma.gov.ru/main.nsf/(ViewDoc)?OpenAgent\&work/dz.nsf/ByID\&BBDEB49CE5B- 
38F1743257CCA0036DF8B, p. 1 (access: 5.07.2015).

Зарубавель Я., “Динамика коллективной памяти”, in: Империя и нация в зеркале исторической памяти. Сборник статей, eds. И. Герасимов, М. Могильнер, А. Семенов, Москва, 2011, pp. 10-29.

Заседание по вопросу подготовки к празднованию 1150-летия зарождения российской государственности, http://www.kremlin.ru/transcripts/12075 (access: 3.09.2014).

Каспшыцка А., "Реформа системы образования в России и формирование исторической памяти граждан”, in: Fenomen Rosji. Pamięć przeszłości i perspektywy rozwoju, cz. 2: Kontekst polityczny i gospodarczy, eds. J. Diec, A. Jach, Kraków, 2014, pp. 109-116.

Конорев С.В., "Исторический миф в современном российском обществе: происхождение и социокультурная роль”, in: Кризисы переломных эпох в исторической памяти, еd. Л.П. Репина, Москва, 2012, pp. 325-333.

Кром М.М., “Политическая антропология: новые подходы к изучению феномена власти в истории России”, Исторические записки, 122 (2001), nо. 4, pp. 370-397.

Лангеноль А., “Общественная память после смены строя: сходства и различия между практиками памяти в посткоммунистических и постколониальных странах”, Ab Imperio, 1 (2004), pp. 365-390.

Леонтьева О.Б., “Историческая память и образы прошлого в культуре пореформенной России", in: Диалоги со временем: память о прошлом в контексте истории, ed. Л.П. Репина, Москва, 2008, pp. 636-681.

Майорова О., “Бессмертный Рюрик: Празднование тысячелетия России в 1862 г., Новое литературное обозрение, 43 (2000), pp. 137-165, http://magazines.russ.ru/nlo/2000/43/ s6.html.

Мироненко С.[В.], 2012 год объявлен годом российской истории, http://www.rusarchives. $\mathrm{ru} /$ statehood/mironenko.shtml (access: 3.06.2015).

Пояснительная записка к проекту федерального закона «О внесении изменений в статью 1 Федерального закона «О днях воинской славы и памятных датах России» и в статью 112 Трудового кодекса Российской Федераиии», http://asozd2.duma.gov.ru/main. nsf/(ViewDoc)?OpenAgent\&work/dz.nsf/ByID\&EB21378905DBD8FC43257CCA0028524E, pp. 1-2 (access: 5.07.2015).

Путин В.В., Послание Президента Федеральному Собранию, 12 декабря 2012 года, http://kremlin.ru/events/president/news/17118 (access: 3.09.2014).

Распоряжение Правительства РФ от 06.02.2012 N 153-р “О плане основных мероприятий по подготовке и проведению празднования 1150-летия зарождения российской государственности", www.consultant.ru/document/cons_doc_EXP_524549 (access: 3.09.2014).

Святославский А.В., История России в зеркале памяти. Механизм формирования исторических образов, Москва, 2013.

Требст Ш., “Какой такой ковёр?’ Культура памяти в посткоммунистических обществах Восточной Европы: попытка общего описания и категоризации”, Ab Imperio, 4 (2004), pp. 41-78.

Указ Президента РФ «О праздновании 1150-летия зарождения российской государственности» 3 марта 2011 года N 267, http://old.rs.gov.ru/sites/rs.gov.ru/ files/1_-_Ukaz_Prezidenta_RF_03_03_2011.pdf (access: 3.09.2014).

Уортман Р.С., Сценарии власти. Мифы и иеремонии русской монархии, vol. 2: Om Александра II до отречения Николая II, Москва, 2004.

Щербинина Н.Г., Мибо-герочческое конструирование политической реальности России, Москва, 2011. 
Mikołaj Banaszkiewicz, Ph.D., his interests include Russian Reformation traditions, history of pre-revolution liberalism in Russia and historical policy of the Russian Federation; he is the author of a doctoral dissertation "Reforms and Social Change in the Russia of Alexander II. Dmitry Milyutin and the "Golos" (The Voice) Newspaper in the Dispute over the State of the Army and Education (Jagiellonian University, Cracow, 2015, 686 pp.) (mikolaj.banaszkiewicz@ gmail.com). 